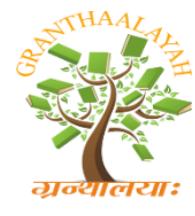

INTERNATIONAL JOURNAL OF RESEARCH GRANTHAALAYAH

A knowledge Repository

Arts

\title{
THE CRAFTS OF MADHYA PRADESH - AN OVER VIEW
}

\author{
Dr Anjali Pandey *1 \\ ${ }^{* 1,2}$ Assistant Professor \& H.O.D., Drawing and Painting Department, Govt. M.L.B. Girls P.G. \\ Autonomous College, Bhopal, India
}

DOI: https://doi.org/10.29121/granthaalayah.v5.i1.2017.1903

\begin{abstract}
In Indian art, the eternal presence of the cosmos remains associated through centuries. Tradition executes to maintain the relationship of man in specific style and technique. All creative activity enjoyed high appreciation and prestige when the hands of a craftsman are engaged in his craft. It is always a ceremonial.

"The aim of the artist is not to extract beauty from the nature but reveal the Life within life, the Noumenon within phenomenon, the reality within unreality and the soul within matter. When it is revealed, beauty reveals itself. It has been the constant endeavor the Indian artist to convey this idea in the words and wood, in the clay and stone, in brass and bronze, and even through music, and dance. The aim has always been the same- to incarnate the infinite in the finite.".
\end{abstract}

Keywords: Commercial Craft; Antiquity; Decorative Items; International Market.

Cite This Article: Dr Anjali Pandey. (2017). “THE CRAFTS OF MADHYA PRADESH - AN OVER VIEW." International Journal of Research - Granthaalayah, 5(1), 291-294. https://doi.org/10.29121/granthaalayah.v5.i1.2017.1903.

\section{Introduction}

India is famous for its handicrafts practiced since ages. Now it becomes the basic part of the life. Many craft traditions flourished here with the local identities. An overview declares the three district categories of Indian craft- folk craft, religions and commercial craft. The cultural diversity the artistic appeal and the regional customs made the Indian craft appreciable in the world market. The splendor of Indian craft reveal in various serviceable and decorative items. Vivid material and technique; commercial and house hold, portrays the sharpness sensibilities of Indian craftsmanship. ${ }^{2}$

Handicrafts are valuable; they enrich our life by their grace. The oldest remains of Indian belong to Indus valley civilization. The delicate carving beds with number of colours in each one express the creative innovation. As 'Art reveals itself'. Each and every age reflects and speaks 
about the creativity, activity, diversity influenced and variety and productivity through the antiquity and modernity. ${ }^{3}$

Madhya Pradesh has rich art and craft tradition. A variety of handicraft items with great demand on national and international market comes out from the hereditary skill of the artisans. A variety of craft objects of bamboo, jute, cane, wood craft, brass and bronze metal craft, iron craft, and stone craft. Terracotta and papier-mâché work, folk painting and stuffed leather toys. Jewelry and Zari work, silk and in textile a verity of silk and cotton saris with block print speaks about the art tradition of Madhya Pradesh. ${ }^{4}$

\section{Metal Craft}

The craftsmen of Madhya Pradesh are practicing the traditional iron craft. Their skills and techniques are molding into various shapes and forms. Gond, Muria, Bhil, Saharia Baiga, Pardhan tribal's, has the custom of offering the horses, Trishuls, Swings etc made out from iron on fulfillment of their wishes to their god.

The metal crafts men of Tikamgarh are giving the shape to their ideas and concepts on with help of metal craft of bell metal craft, Jwellery boxes, Idols of deities, images and many other articles are the verdict, folk and tribal jewelries have their distinct styles on gold, silver, bronze and mix metal. Now these days' craftsmen's are working at wood and other materials also. ${ }^{5}$

\section{Wood Craft}

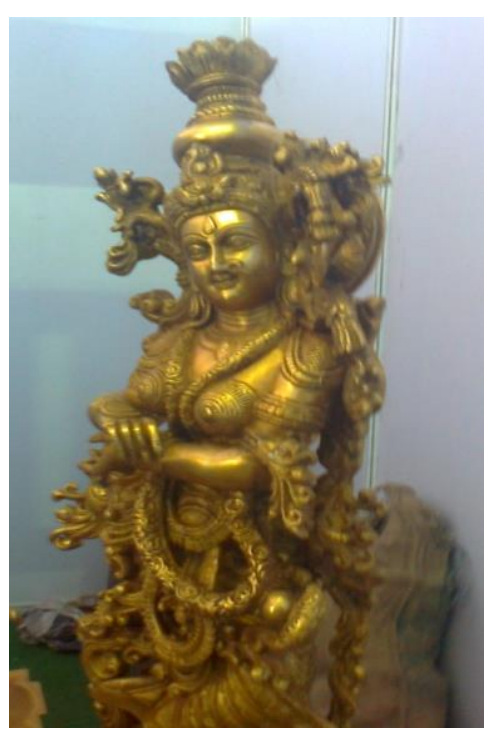

The wood workers of Madhya Pradesh uphold the traditions of their fore fathers. The art of wood carving have flourished in many parts of state. Embellished wooden ceilings, doors and lintels with finely carved designs, which is a silent testimonial of its glory State. The art traditions of elaborate wood work for both utilitarian and architectural purpose are found here. The artisans of Malwa, Nimar, Bundelkhand, Rewa, Piparia makes Doors, Window, Frames, Masks and sculptures.

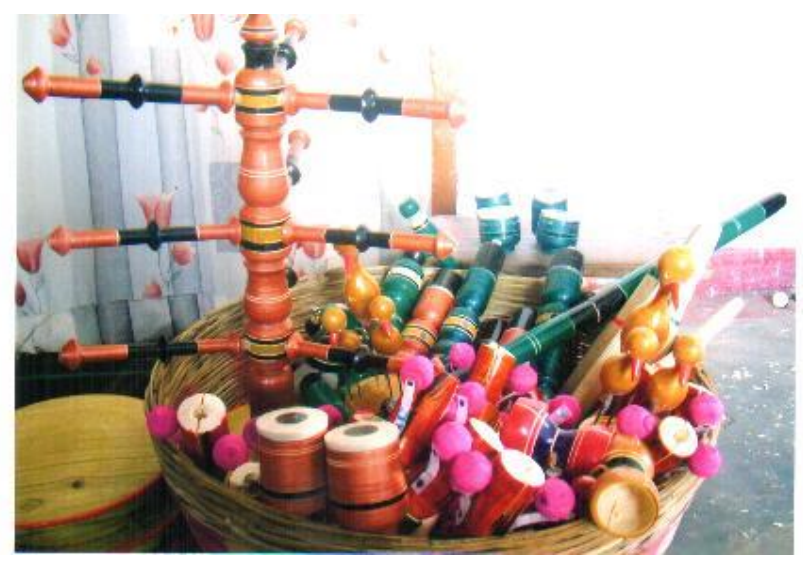
Beside these articles, Budhni, Sheopur-Kalan, Gwalior, Rewa offers the variety of painted and lacquered wood craft items as toys, boxes, cradle posts, bed-posts, flower-vases etc. ${ }^{6}$

\section{Paper Machie}

Paper machie is craft existing since long time. The artisans of Gwalior, Bhopal, Ratlam and Ujjain are ornating the articles like vases, flower pots and Jwellery boxes. Birds, animals, dolls, and statue, other is in show cases. Now these days the Jwellery of paper machie is also in vogue. ${ }^{7}$ 


\section{Dolls}

Dolls are the foremost choice in all over the world for the girls. The vast productions of dolls are in Gwalior, Bhopal and Jhabua (Madhya Pradesh). In Madhya Pradesh the work of bamboo is in the Shahdol, Mandla, Balaghat and Seoni regions after the Chhattisgarh. The artisans of this region are really very skill full and has old knowledge and skills. ${ }^{8}$

\section{Clay Molding}

The art of molding the clay has also finest examples. The potters of Madhya Pradesh are symbolizing their craftsmanship with maturity. Horses, birds, statue of elephants and some other articles can be seen in pink, red, brown or dark grey colors. ${ }^{9}$

\section{Leather Craft}

Craftsmen of Devas, Indore, and Gwalior are engaged in making leather toys, bags, leather, garments, shoes and other articles. Gwalior, Indore, and Bhopal are also producing jute articles for decorative purposes. ${ }^{10}$

\section{Textile}

Madhya Pradesh is also has its specific identity in textile. The Malwa, Nimar, Ujjain, Javad, Kukshi, Dhar, Manavar, Indore

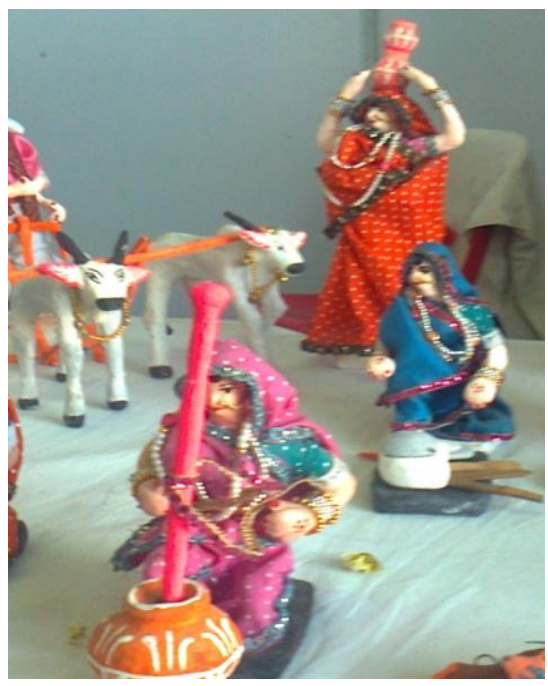
and Mandsor have a wide range of hand block printing, quilts with natural dyes. Mandsor, Indore and Ujjain are famous for the bandhnies.

The batike work is designed and colored at Bhairogarh near Ujjain and Indore. The weavers of Chanderi and Maheshwar have the specialization for its delicate weave all over the world. They are continuously experiencing their work having their own traditional trend. ${ }^{11}$

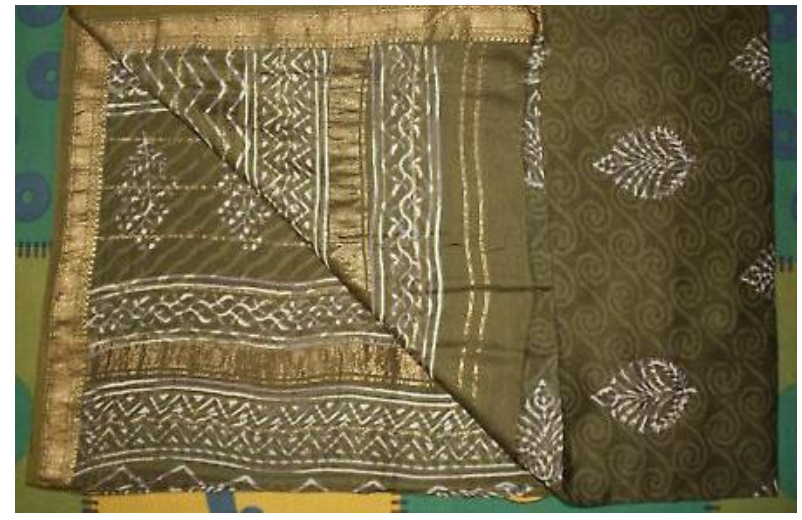


In recent years new forms introduced, the crafts man modified the forms according to their own requirements without changing their basic structure. In contemporary field the craft work is involved with physical, psychological and technological co-ordination. Now the art embraced the full range of skill craft, creative activity, creative imagination, ritual and economical practices related with technical and aesthetical expressions. The variety of wooden articles, idols and toys displayed during social customs in every region of India. Many idols, wooden ware, and toys created for the occasion of birth, marriage and death ceremonies or during other activities. Here the sociology of the craft-culture is not only provides the utility in daily life, amusement for the children it also cultivates the social pattern and weaves the new Tana-Bana for the society. They generate the value system, and modified the behavior pattern, according to the need for equilibrium and coherence in society.

\section{References}

[1] Sahai Baldeo :Indian Heritage, Pub Div; New Delhi;2005

[2] Kamla Devi Chattopadyaya: Bhartiya hastashilp parampara;Pub Div New Delhi;1991; pg-17-53

[3] Ibid: Pg-1-4

[4] http//www.mapsofindia./Madhya-Pradesh/arts-and-crafts.html;Arts and Crafts of Madhya Pradesh

[5] Pandey Anjali: The Changing Pattern Of Design In Bell Metal;Souvenir,Issue-2/Pg34-362013/ Some Aspect Of Traditional Toys In Indian Art And Culture;International Journal Of Social And Life Sciencesvol-Xvii-1Dec2014/Pg-86-92

[6] www.indianetzone/indian crafts/woodcraft of central india

[7] Pandey Anjali:Woodcraft of Madhya Pradesh;U.G.C.M.R.P.2011;pg 36-38

[8] Ibid

[9] Ibid

[10] Ibid

[11] Ibid

[12] Ibid pg-124-125

*Corresponding author.

E-mail address: anjali_pandey11@yahoo.com 